\title{
Evaluation of Oxidation Performance of TRISO Fuel Particles for Postulated Air-Ingress Accident of HTGR
}

\author{
Fangcheng Cao $\mathbb{D}^{1,}{ }^{1,2}$ De Zhang, ${ }^{2}$ Qingjie Chen, ${ }^{1}$ Hao Li, ${ }^{1}$ and Hongqing Wang $\mathbb{D}^{1}$ \\ ${ }^{1}$ School of Chemistry and Chemical Engineering, University of South China, Hengyang Hunan 421001, China \\ ${ }^{2}$ Cooperative Innovation Center for Nuclear Fuel Cycle Technology and Equipment, University of South China, \\ Hengyang Hunan 421001, China \\ Correspondence should be addressed to Hongqing Wang; hqwang2015@126.com
}

Received 6 March 2020; Accepted 24 April 2020; Published 22 May 2020

Guest Editor: Yuxin Wang

Copyright (c) 2020 Fangcheng Cao et al. This is an open access article distributed under the Creative Commons Attribution License, which permits unrestricted use, distribution, and reproduction in any medium, provided the original work is properly cited.

\begin{abstract}
In a high-temperature gas-cooled reactor, the integrity of tristructural-isotropic-(TRISO-) coated fuel particles ensures the safety of the reactor, especially in case of an air-ingress accident. The oxidation of TRISO particles with the outer layers of silicon carbide (SiC) was performed at temperatures of $900^{\circ} \mathrm{C}-1400^{\circ} \mathrm{C}$ in air environment. Both the microstructure and phase composition of the $\mathrm{SiC}$ layers were studied. The results showed that the $\mathrm{SiC}$ layers had a good oxidation resistance below $1100^{\circ} \mathrm{C}$. However, the amorphous silica on the $\mathrm{SiC}$ layers formed at $1200^{\circ} \mathrm{C}$ and gradually crystallized at $1400^{\circ} \mathrm{C}$ with the presence of microcracks. The reaction rates of the $\mathrm{SiC}$ layers were determined by measuring the silica thickness. It was proposed that the oxidation of the SiC layers followed the linear-parabolic law with the activation energy of $146 \pm 5 \mathrm{~kJ} / \mathrm{mol}$. The rate-determining step of the oxidation was the diffusion of oxygen in silica.
\end{abstract}

\section{Introduction}

The high-temperature gas-cooled reactor (HTGR) is considered as one of the promising reactors in the Generation IV nuclear energy system. The HTGR reference concept is a helium-cooled, graphite-moderated, thermal neutron spectrum reactor with a target coolant outlet temperature of $\sim 900^{\circ} \mathrm{C}$. The high outlet temperature offers higher efficiency electricity generation and new opportunities for a broad spectrum of process heat applications, including hydrogen production by thermochemical water splitting or hightemperature electrolysis [1]. The success of HTGR is due to its inherent safety characteristics, which rely closely upon the quality and integrity of the tristructural-isotropic- (TRISO-) coated fuel particles [2].

In the current reference TRISO-coated particle design, the kernel (microsphere) is typically formed from enriched uranium dioxide $\left(\mathrm{UO}_{2}\right)$ or uranium oxycarbide (UCO) and is surrounded by successive layers of porous pyrocarbon buffer, dense inner pyrolytic carbon (IPyC), silicon carbide $(\mathrm{SiC})$, and dense outer pyrolytic carbon (OPyC). The $\mathrm{SiC}$ layer, in particular, provides structural support to accommodate internal gas pressure and serves as the primary barrier to the release of fission products [3]. Therefore, the microstructure and properties of the SiC layer are essential to the safety of the reactors under operation conditions, even during any accidents, in the case of failure of all active cooling systems and complete loss of forced cooling.

Under normal operation conditions, the fuels work in helium loops and withstand a working temperature of $\sim 1000^{\circ} \mathrm{C}$ in the HTGR. The highest normal operating fuel temperature should not be greater than $1250^{\circ} \mathrm{C}$. In previous studies, postulated air-ingress accidents have got a lot of attention to the safety analyses of HTGR. In the case of offnormal transients, air ingress can result from breaches in the reactor system that link the internal and external gaseous atmospheres. The maximum fuel temperature might rise to $1300^{\circ} \mathrm{C}-1400^{\circ} \mathrm{C}$. Under normal pressure and 
high temperature air environment, the core components, including the fuel elements, would suffer extensive degradation and lead to a significantly enhanced release of fission products [4]. The oxidation of graphite is of primary importance with respect to the structural integrity of the graphite [5]. Much effort has been devoted to the consequences of graphite oxidation. The oxidation performance of matrix graphite under air-ingress accident conditions has not only been simulated under the conservative assumptions but also been studied thermogravimetrically for various oxygen concentrations and with temperatures from $600^{\circ} \mathrm{C}$ to $1600^{\circ} \mathrm{C}[6-8]$. However, the matrix graphite of fuel elements is susceptible to oxidation damage. Once the graphite matrix of the compact or pebble fuel elements has been oxidized away, it may lead to the exposure of TRISO fuel particles and increase the risk of radioactivity release. The consequences of air-ingress for TRISO fuel particles have not been adequately addressed to date. Despite the rare probability of this accident, the oxidation behavior of the TRISO particle is of great importance for protecting the reactor core and decreasing the risk of radioactivity release in case of air-ingress accidents. As the $\mathrm{OPyC}$ layers begin to be oxidized at temperatures higher than $700^{\circ} \mathrm{C}$, the exposed $\mathrm{SiC}$ layers in TRISO particles would play an important role in governing fuel performance. Therefore, the investigation of the oxidation performance of the $\mathrm{SiC}$ layers is imperative in the safety considerations.

The air oxidation of $\mathrm{SiC}$ materials (e.g., sintered $\alpha$-SiC, high-purity $\beta$-SiC, and SiC-based composites) has attracted tremendous research interest for decades, due to its wide application in high-temperature components [9-11]. Two forms of $\mathrm{SiC}$ oxidation, such as the passive oxidation regime (weight gain) and the active oxidation (weight loss), were reported. $\mathrm{SiC}$ forms a silica layer comparable to silicon, and the oxidation of both materials follows a linearparabolic or parabolic law. However, since the microstructure and properties of the SiC layers in TRISO particles are different from those of the SiC plate despite the same coating procedure, the oxidation mechanisms of the $\mathrm{SiC}$ layers are also needed to be clarified [12]. The impact of annealing in air atmosphere on TRISO particles has been investigated with temperatures up to $1600^{\circ} \mathrm{C}$ [13-15]. The results showed that intense regression of the $\mathrm{SiC}$ beneath the rough silica layer occurred at $1600^{\circ} \mathrm{C}$, which was affected by the interaction between TRISO particles and the alumina crucible [13]. The mechanisms and kinetics of the oxidation process of the TRISO particles with the outer layers of $\mathrm{SiC}$ in air environment under different temperatures still need to be investigated to evaluate the microstructure evolution of the silica layer.

In the present work, the oxidation of TRISO particles with the outer layers of $\mathrm{SiC}$ was investigated in air environment at the temperature range of $900^{\circ} \mathrm{C}-1400^{\circ} \mathrm{C}$. The composition and microstructure of the $\mathrm{SiC}$ layers after oxidation was characterized and analyzed. The oxidation kinetics of the $\mathrm{SiC}$ layer were studied, including oxidation rate, activation energy, and the rate-controlling step, which aims to predict the $\mathrm{SiC}$ degradation rate in case of an airingress accident in operation.

\section{Experimental Procedure}

2.1. High-Temperature Oxidation. The TRISO particle samples were made by fluidized bed chemical vapor deposition using zirconia particles with a diameter of $\sim 500 \mu \mathrm{m}$ as simulated kernels. The average thickness of the buffer, IPyC, SiC, and OPyC layers was $200 \mu \mathrm{m}, 40 \mu \mathrm{m}, 24 \mu \mathrm{m}$, and $40 \mu \mathrm{m}$, respectively. Before the oxidation test, the TRISO particle samples were exposed in air at $800^{\circ} \mathrm{C}$ for 8 hours to oxidize the OPyC layers and obtain the TRISO particles with the outer layers of $\mathrm{SiC}$, as shown in Figure 1.

High-temperature oxidation behavior for the TRISO particles with the outer layers of $\mathrm{SiC}$ was investigated in atmospheric environment at $1 \mathrm{~atm}$ pressure under the isothermal conditions. The furnace was horizontally held with an alumina tube and has a $20 \mathrm{~cm}$ long hot zone. The TRISO particle samples were placed on the platinum crucible in the alumina reaction tube with both ends open. The samples were heated from room temperature at the programmed heat rate of $5^{\circ} \mathrm{C} / \mathrm{min}$ up to the testing temperatures $\left(900^{\circ} \mathrm{C}-1400^{\circ} \mathrm{C}\right)$. After keeping at the testing temperature for the desired time $(0-48 \mathrm{~h})$, the samples were cooled to room temperature in furnace naturally. To minimize contamination, the alumina reaction tube was aged in atmospheric environment for $50 \mathrm{~h}$ at $1400^{\circ} \mathrm{C}$ before beginning the experiments. Besides, the effects of interaction between the TRISO particle samples and the platinum crucible were neglected in the present work.

2.2. Characterization. The surface morphology and crosssection microstructure of the $\mathrm{SiC}$ layers in TRISO particles was characterized using a scanning electron microscope (SEM) (Inspect F50, FEI, US). The thickness of the silica on the $\mathrm{SiC}$ layer after oxidation was measured at approximately twenty points at the cross sections of TRISO particles. The phases of reactive products on the surfaces of TRISO particles were examined by X-ray diffraction (XRD) (Ultima IV, Rigaku, Japan) and by Raman spectroscopy (LabRAM HR Evolution, Horiba, France) with an incident laser beam of $532 \mathrm{~nm}$ (Nd: YAG). The XRD samples were made by around a number of 20 particles, which were pasted onto a horizontal glass slide and kept closely packed using the silicone paste that has no XRD spectra. For Raman spectroscopy measurement, the TRISO particle was placed on the sample stage under the Raman microscope objective. And the 50x microscope objective was used to focus the laser and collected the backscattered light.

\section{Results and Discussion}

3.1. The Microstructure of the SiC Layers. Figure 2 shows the surface morphology of the $\mathrm{SiC}$ layers before and after oxidation at different temperatures for $24 \mathrm{~h}$. The as-deposited $\mathrm{SiC}$ layer exhibited faceted morphology on the outer surface (Figure 2(a)). No significant variation in the morphology was observed after oxidation below $1100^{\circ} \mathrm{C}$ (Figure 2(b)). However, the edge of the $\mathrm{SiC}$ grains became smooth after oxidation at $1200^{\circ} \mathrm{C}$, which indicates the oxidation of $\mathrm{SiC}$ 


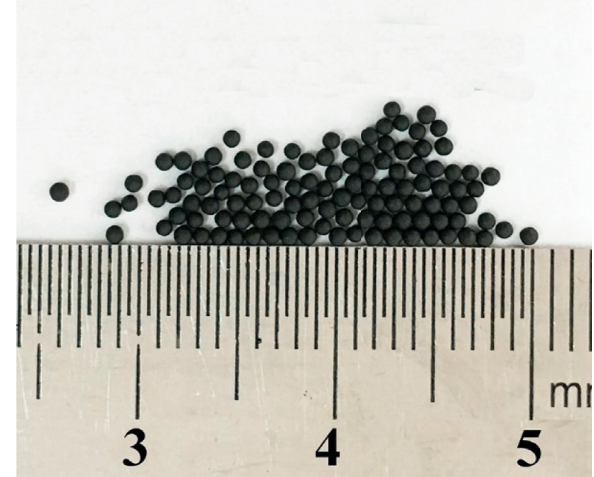

(a)

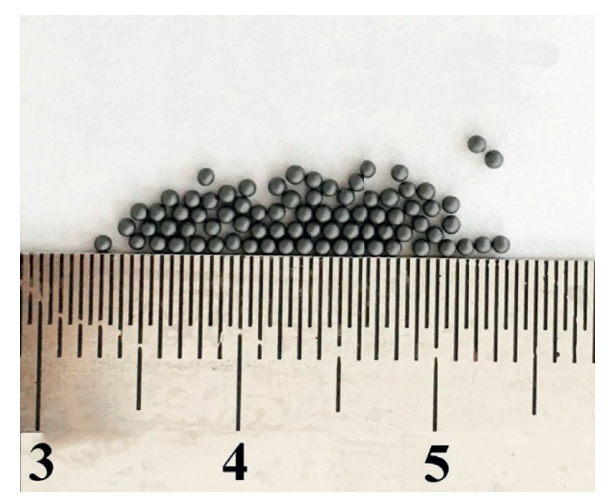

(b)

FIgURE 1: TRISO particle samples (a) with the OPyC layers and (b) without the OPyC layers.
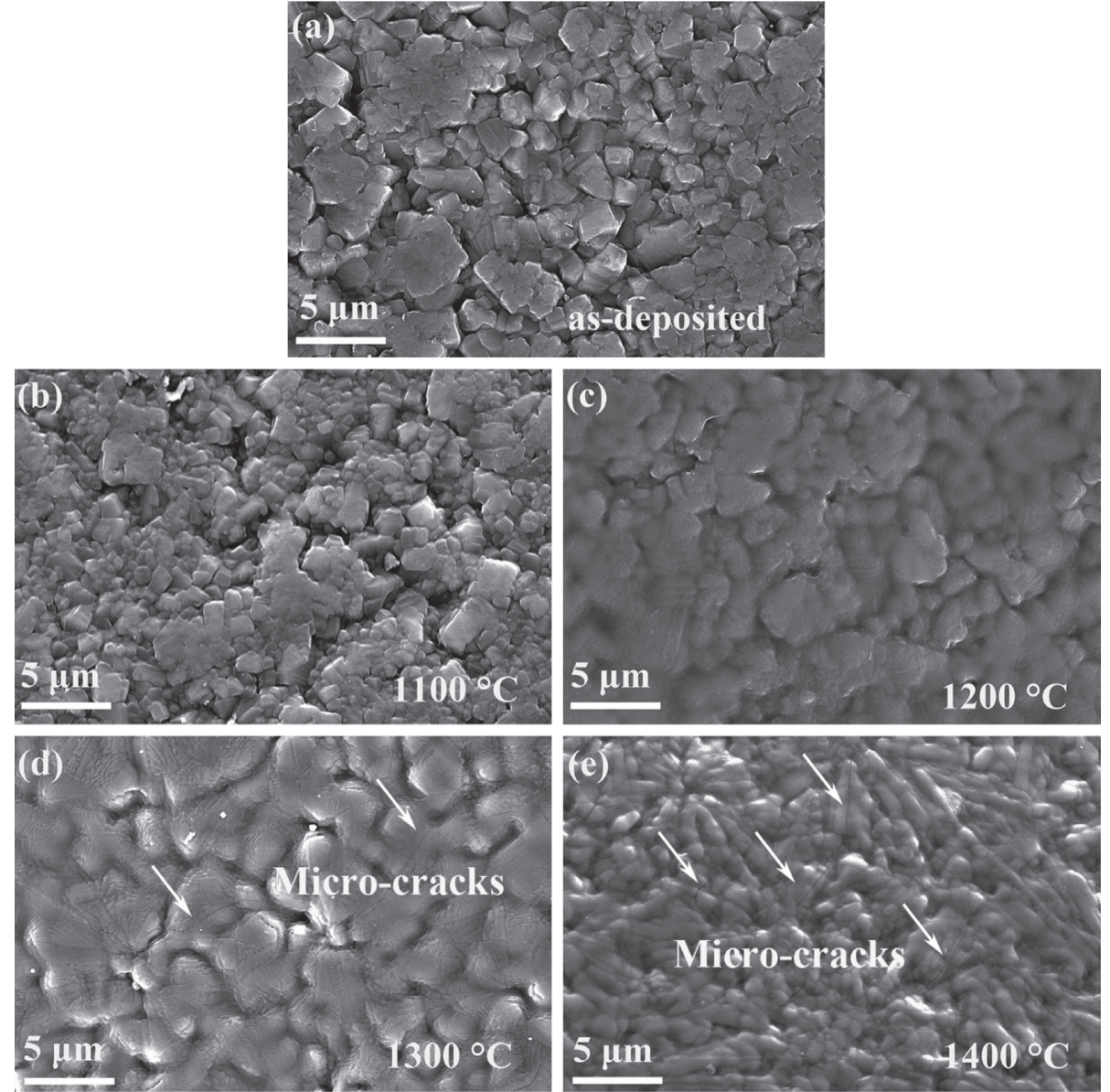

Figure 2: The outer-surface SEM morphology of the SiC layers of (a) as-deposited and after exposure in air at a temperature of (b) $1100^{\circ} \mathrm{C}$, (c) $1200^{\circ} \mathrm{C}$, (d) $1300^{\circ} \mathrm{C}$, and (e) $1400^{\circ} \mathrm{C}$ for $24 \mathrm{~h}$

occurred (Figure 2(c)). Because the oxidation temperature was not high enough to cause an obvious change of the surface morphology, just the sharp edge became smooth could be observed. Besides, the thickness of the oxide layer was too thin to cover the faceted morphology of the SiC grains. Thus, there were still some pits that could not be covered by the oxide layer, where the oxidation would occur.
After oxidation at $1300^{\circ} \mathrm{C}$, the surface morphology changed from multifaceted to smooth with the formation of a thin oxide layer (Figure 2(d)). The SiC grains were almost covered by the formation of the oxide layer, which could prevent inward diffusion of oxygen and the oxidation of SiC. When the oxidation temperature was further increased to $1400^{\circ} \mathrm{C}$, apparent oxidation occurred with the increasing amount of 
oxide on the SiC surface (Figure 2(e)). The surface of the oxide scale appeared a combination of elongated and spherulitic structure, which is the characteristic of the cristobalite formation. As reported, during the crystallization of amorphous silica, the nucleation of silica grains forms elongated structure and then turns to spherulitic structure with the growth of silica grains [16]. That is the reason why the elongated and spherulitic structure could be observed after high-temperature oxidation of SiC. Meanwhile, microcracks formed in the oxide layer (Figures $2(\mathrm{~d})$ and $2(e))$, which could be due to the volume change from the crystallization of amorphous silica and the phase transformation of crystallized silica during the cooling process. The formation of microcracks would reduce the protection of the oxide layer for $\mathrm{SiC}$ from oxidation. What is worse, a significant volume change might also loosen the structure of the oxide layer and lead to poor adhesion at the interface of the oxide layer and $\mathrm{SiC}$.

Figure 3 shows the cross-section microstructure of the $\mathrm{SiC}$ layers before and after oxidation at the temperatures of $1100^{\circ} \mathrm{C}-1400^{\circ} \mathrm{C}$ for $24 \mathrm{~h}$. There were no significant microstructure differences observed from the cross section between the as-deposited $\mathrm{SiC}$ layer and the $\mathrm{SiC}$ layer after oxidation at $1100^{\circ} \mathrm{C}$. However, a thin oxide layer on the $\mathrm{SiC}$ coating was appeared after oxidation at $1200^{\circ} \mathrm{C}$, and the thickness was about $0.41 \mu \mathrm{m}$. Due to the roughness of the asdeposited $\mathrm{SiC}$ layer, the oxide layer was rather rough. After oxidation at $1300^{\circ} \mathrm{C}$, the thickness of the oxide layer increased to $\sim 0.7 \mu \mathrm{m}$. Besides, the surface of the oxide layer became more flat, which indicates the oxide had filled in the roughness of the as-deposited $\mathrm{SiC}$ layer. When the oxidation temperature was further increased to $1400^{\circ} \mathrm{C}$, the thickness of the oxide layer increased significantly to $\sim 1.24 \mu \mathrm{m}$. No through-thickness cracks were observed.

3.2. The Phase Composition of the SiC Layers. Figure 4 shows the effects of oxidation temperature on the XRD patterns of TRISO particles after oxidized for $24 \mathrm{~h}$. Three typical phases could be identified in the XRD pattern of the as-deposited sample, namely, $\mathrm{ZrO}_{2}, \mathrm{PyC}$, and $\mathrm{SiC}$. To amplify the small peaks, the $Y$-axis was plotted to the sqrt (intensity) (Figure 4(b)). At temperatures below $1300^{\circ} \mathrm{C}$, no oxide phase was detected. After oxidation at $1400^{\circ} \mathrm{C}$, diffraction peaks corresponding to the silica phase appeared with weak intensity. The results showed that the silica formed was amorphous at $1200^{\circ} \mathrm{C}-1300^{\circ} \mathrm{C}$ and gradually crystallized at $1400^{\circ} \mathrm{C}$. It was coincident with the evolution of surface morphology observed in Figure 2. Besides, the major crystalline silica phase was detected to be $\alpha$-cristobalite.

Raman spectroscopy was also employed to characterize the phase composition of TRISO particles after oxidation at different temperatures. Raman spectra of $\mathrm{SiC}$ showed two first-order peaks at around $796 \mathrm{~cm}^{-1}$ (TO band) and $972 \mathrm{~cm}^{-1}$ (LO band) with the second-order band between $1400 \mathrm{~cm}^{-1}$ and $1800 \mathrm{~cm}^{-1}$, which corresponds to stoichiometry $\beta$-SiC. Significant differences in the Raman spectra at ranges of $100 \mathrm{~cm}^{-1}-550 \mathrm{~cm}^{-1}$ and $1200 \mathrm{~cm}^{-1}-1850 \mathrm{~cm}^{-1}$ were observed, as shown in Figure 5. When the oxidation temperature increased to $1400^{\circ} \mathrm{C}$, the peaks at $110 \mathrm{~cm}^{-1}$, $230 \mathrm{~cm}^{-1}$, and $417 \mathrm{~cm}^{-1}$ appeared which correspond to the existence of silica. The results were consistent with the XRD analyses. Besides, the $D$ band $\left(1350 \mathrm{~cm}^{-1}\right)$ and $G$ band $\left(1600 \mathrm{~cm}^{-1}\right)$ that are the first-order band of carbon also appeared with the increase of oxidation temperature above $1200^{\circ} \mathrm{C}$, suggesting that the carbon was in form of amorphous structure [17]. The results revealed the formation of carbon occurred during the oxidation of $\mathrm{SiC}$ at high temperatures. The low intensity of the $D$ and $G$ bands indicates a small proportion of carbon produced after high-temperature oxidation of $\mathrm{SiC}$, which was identified at the $\mathrm{SiC} / \mathrm{SiO}_{2}$ interface in the previous studies by transmission electron microscopy [18].

3.3. The Oxidation Behavior of the SiC Layers. To study the oxidation behavior of the SiC layers in TRISO particles, oxidation tests were further performed at different temperatures for different times. The oxide layer thickness as a function of the oxidation time is shown in Figure 6. When the temperature was below $1000^{\circ} \mathrm{C}$, the changes in the surface morphology of the $\mathrm{SiC}$ layer were barely noticeable. It indicates that the $\mathrm{SiC}$ had good oxidation resistance at a temperature below $1000^{\circ} \mathrm{C}$. Besides, it seems no measurable oxidation occurred at $1100^{\circ} \mathrm{C}$ within $36 \mathrm{~h}$ exposure until the oxidation time was prolonged to $48 \mathrm{~h}$. The dense oxide layer produced on the surface of the $\mathrm{SiC}$ layer could prevent the inward diffusion of oxygen. With the increase of oxidation temperature, the diffusion rate of oxygen in the silica increased, so did the oxidation rate. As a result, the thickness of the silica layer increased obviously with the increase of oxidation time at the higher temperature $\left(\geq 1200^{\circ} \mathrm{C}\right)$. As shown in Figure 6, the silica layer thickness was $1.9 \mu \mathrm{m}$ after exposure at $1400^{\circ} \mathrm{C}$ for $48 \mathrm{~h}$, which is almost twice that at $1300^{\circ} \mathrm{C}$ for the same dwelling time.

When $\mathrm{SiC}$ material is exposed in air environment under high temperature, a dense silica layer would be formed on the $\mathrm{SiC}$ surface. The inward diffusion of oxygen through the oxide layer is impeded, which inhibits further oxidation of the underlying $\mathrm{SiC}$. As a result, the oxidation of $\mathrm{SiC}$ would be slow, which leads to the regression of $\mathrm{SiC}$ within the passive oxidation regime. In air environment at high temperature, the passive oxidation between $\mathrm{SiC}$ and oxygen is expressed by the following equation $[9,19]$ :

$$
\mathrm{SiC}(\mathrm{s})+\frac{3}{2} \mathrm{O}_{2}(\mathrm{~g})=\mathrm{SiO}_{2}(\mathrm{~s})+\mathrm{CO}(\mathrm{g})
$$

Figure 7 shows the oxidation kinetics of $\mathrm{SiC}$ in air environment using a dual logarithm coordinate. In the dual logarithm coordinate, a linear oxidation law presents a linear with a slope of 1 , while a parabolic oxidation law presents a linear with a slope of 0.5 [20]. However, the slopes derived from Figure 7 were in a range of 0.75 to 0.67 , which decreased with the increase of oxidation temperature. It indicates that the oxidation kinetics at the temperature range of $1200^{\circ} \mathrm{C}-1400^{\circ} \mathrm{C}$ could not be expressed using a simple linear or parabolic law. That is, the oxidation evolves both linear and parabolic law, which is reported as 


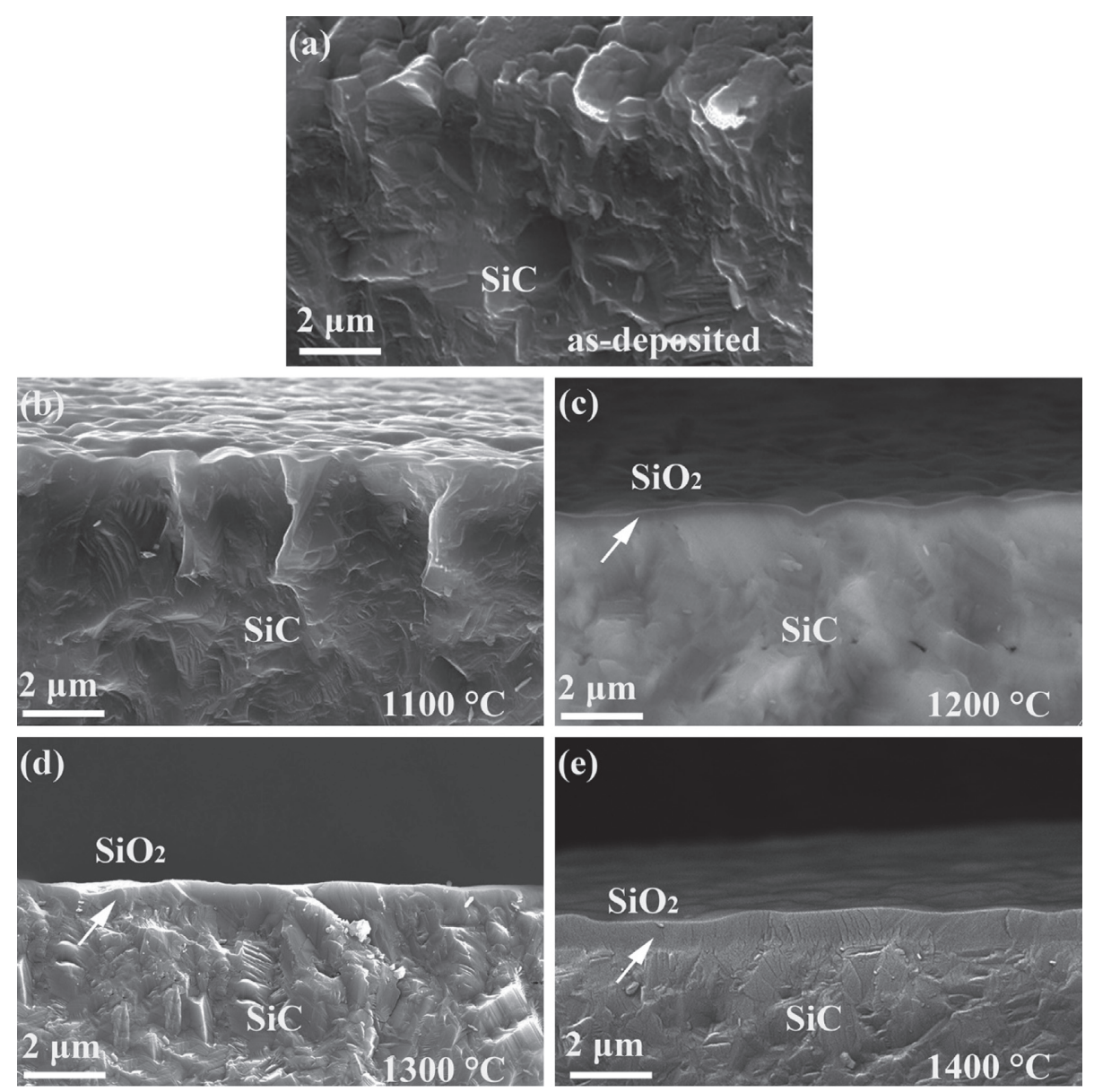

FIgURE 3: The fracture cross-section SEM morphology of the SiC layers of (a) as-deposited and after exposure in air at a temperature of (b) $1100^{\circ} \mathrm{C}$, (c) $1200^{\circ} \mathrm{C}$, (d) $1300^{\circ} \mathrm{C}$, and (e) $1400^{\circ} \mathrm{C}$ for $24 \mathrm{~h}$.

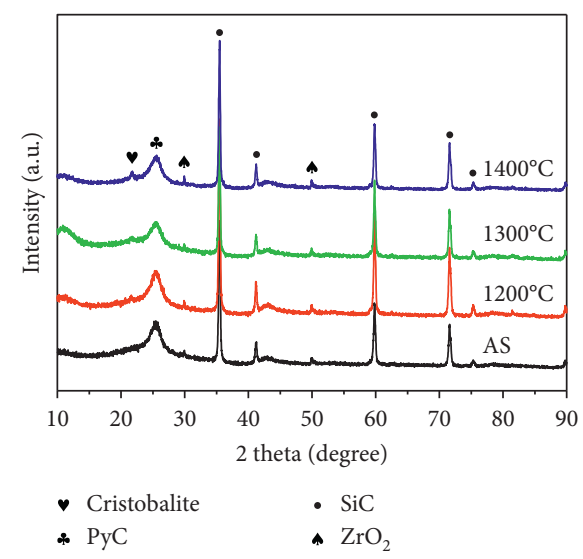

(a)

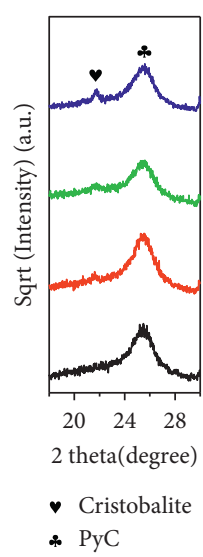

(b)

Figure 4: XRD patterns of TRISO particles. (a) Both as-deposited sample and the samples after air oxidation for $24 \mathrm{~h}$ at $1200^{\circ} \mathrm{C}-1400^{\circ} \mathrm{C}$ and (b) amplified XRD patterns from $18^{\circ}-30^{\circ}$.

the linear-parabolic law. For the linear-parabolic law, the Deal-Grove model is often used to describe the relationship between the thickness of silica and the oxidation time, as follows [20]:

$$
x^{2}+A x=B t,
$$

where $x$ is the silica thickness $(\mu \mathrm{m}), t$ is the oxidation time $(\mathrm{h})$, $B / A$ is the linear oxidation rate $(\mu \mathrm{m} / \mathrm{h})$, and $B$ is the parabolic 


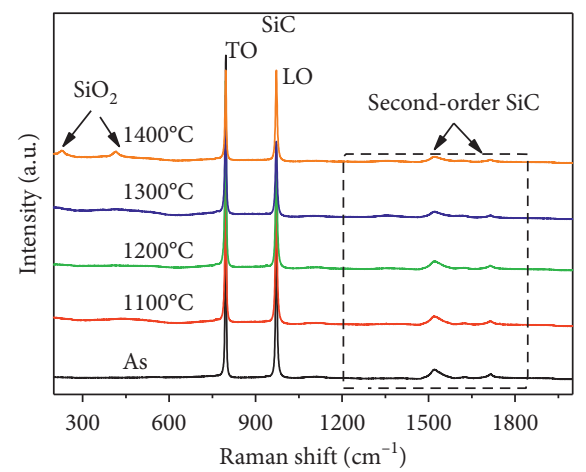

(a)

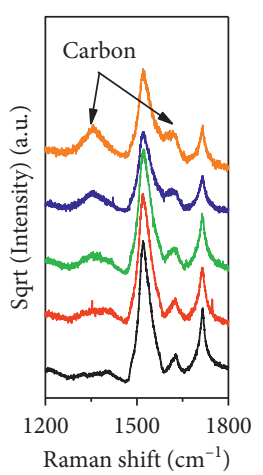

(b)

Figure 5: Raman spectra of TRISO particles. (a) Both as-deposited sample and the samples after air oxidation at $1200^{\circ} \mathrm{C}-1400^{\circ} \mathrm{C}$ for $24 \mathrm{~h}$ and (b) amplified Raman spectra from $1200 \mathrm{~cm}^{-1}-1800 \mathrm{~cm}^{-1}$.

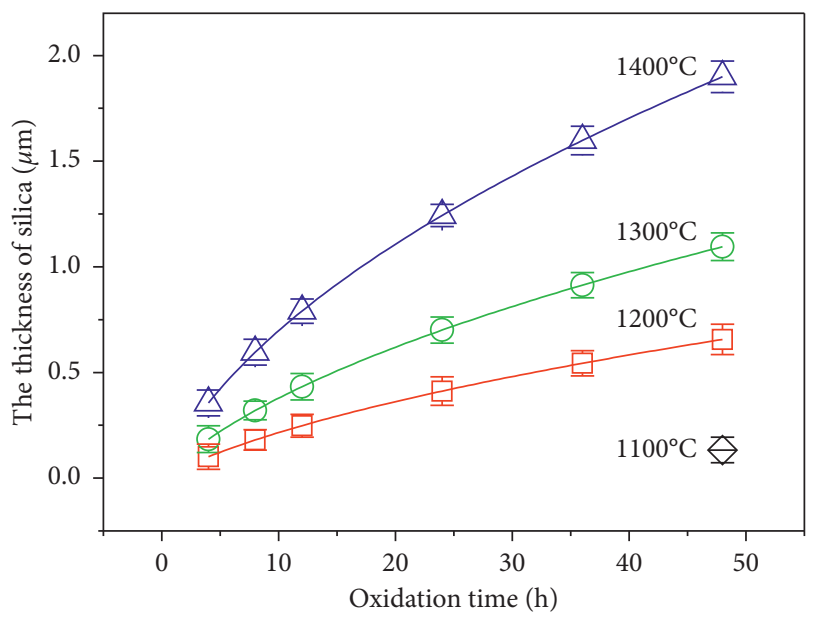

FIGURE 6: The thickness of the silica layer as a function of oxidation time under different temperatures in air atmosphere.

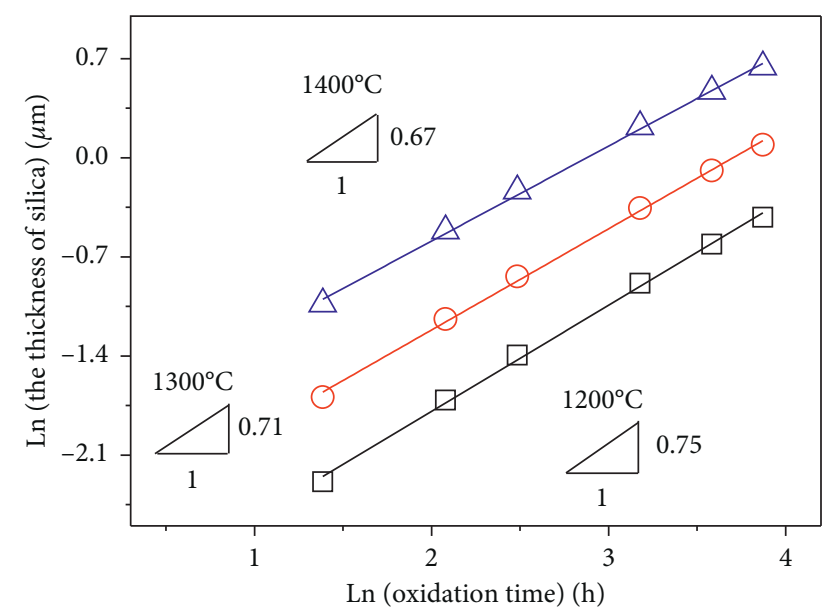

Figure 7: Oxidation kinetics of the $\mathrm{SiC}$ layer in air environment using a dual logarithm coordinate.

oxidation rate $\left(\mu \mathrm{m}^{2} / \mathrm{h}\right)$. It is noted that $B / A$ and $B$ are the rate coefficients for the interfacial reaction and the diffusion of oxidants, respectively. By fitting the relationship between the silica thickness and the oxidation time using equation (2), both the linear and parabolic rates were obtained and are summarized in Table 1. The linear and parabolic oxidation rates of $\mathrm{SiC}$ significantly increased with the increase of temperature. The growth rates of the silica oxidized at $1400^{\circ} \mathrm{C}$ are a little lower than the reported values (Table 1) [14]. According to the oxidation kinetics of the SiC layers, the microstructure evolution of the silica under different temperatures in air environment could be evaluated.

Meanwhile, the temperature dependence of the oxidation rate can be described using the Arrhenius equation:

$$
k=K_{0} \cdot \exp \left(\frac{-E_{\mathrm{a}}}{R T}\right),
$$

where $k$ is the oxidation rate $\left(\mu \mathrm{m}^{2} / \mathrm{h}\right)$, which is corresponding to the parabolic oxidation rate in this study, $K_{0}$ is the frequency factor $\left(\mu \mathrm{m}^{2} / \mathrm{h}\right), E_{\mathrm{a}}$ is the activation energy $(\mathrm{kJ} /$ $\mathrm{mol}), \quad R$ is the ideal gas constant $\left(R=8.314 \times 10^{-3} \mathrm{~kJ} /\right.$ $(\mathrm{mol} \cdot \mathrm{K}))$, and $T$ is the temperature $(K)$. Using equation (3) to fit the experimental data, the activation energy $\left(E_{\mathrm{a}}\right)$ can be estimated. Figure 8 shows the Arrhenius plot of the obtained parabolic rate constant versus temperature. The activation energy of the parabolic rates was yielded to be $146 \pm 5 \mathrm{~kJ} / \mathrm{mol}$ at the temperature range of $1200^{\circ} \mathrm{C}-1400^{\circ} \mathrm{C}$. As reported in the previous literature, the activation energy values have ranged from $120 \mathrm{~kJ} / \mathrm{mol}$ to $400 \mathrm{~kJ} / \mathrm{mol}[14,21,22]$. There is a general trend that the higher the temperature, the greater the activation energy. It is commonly accepted that the relatively low activation energy of $80 \mathrm{~kJ} / \mathrm{mol}-120 \mathrm{~kJ} / \mathrm{mol}$ may correspond to the permeation of oxygen molecule in amorphous silica and the high activation energy of $230 \mathrm{~kJ} / \mathrm{mol}-400 \mathrm{~kJ} /$ mol may suggest the diffusion of oxide ion in amorphous silica or cristobalite [22]. The activation energy value obtained in the present work $(146 \pm 5 \mathrm{~kJ} / \mathrm{mol})$ is close to value for the diffusion of the oxygen molecules in amorphous silica. Therefore, the rate-controlling step was likely the diffusion of the oxygen molecules in the silica [23].

The continuing oxidation of $\mathrm{SiC}$ relies on the diffusion of oxygen through the covering silica layer, and thus, the diffusion kinetics control the oxidation rate of SiC. Initially, the formed layer was amorphous, but at temperatures above 
TABLE 1: Summary of the linear and parabolic oxidation rates of the $\mathrm{SiC}$ layers in TRISO particles.

\begin{tabular}{lcc}
\hline Oxidation temperature $\left({ }^{\circ} \mathrm{C}\right)$ & $\begin{array}{c}\text { Linear rate } \\
(\mu \mathrm{m} / \mathrm{h})\end{array}$ & Parabolic rate $\left(\mu \mathrm{m}^{2} / \mathrm{h}\right)$ \\
\hline 1200 & 0.030 & 0.017 \\
1300 & 0.058 & 0.042 \\
1400 & 0.125 & 0.121 \\
& $0.165[14]$ & $0.126[14]$ \\
\hline
\end{tabular}

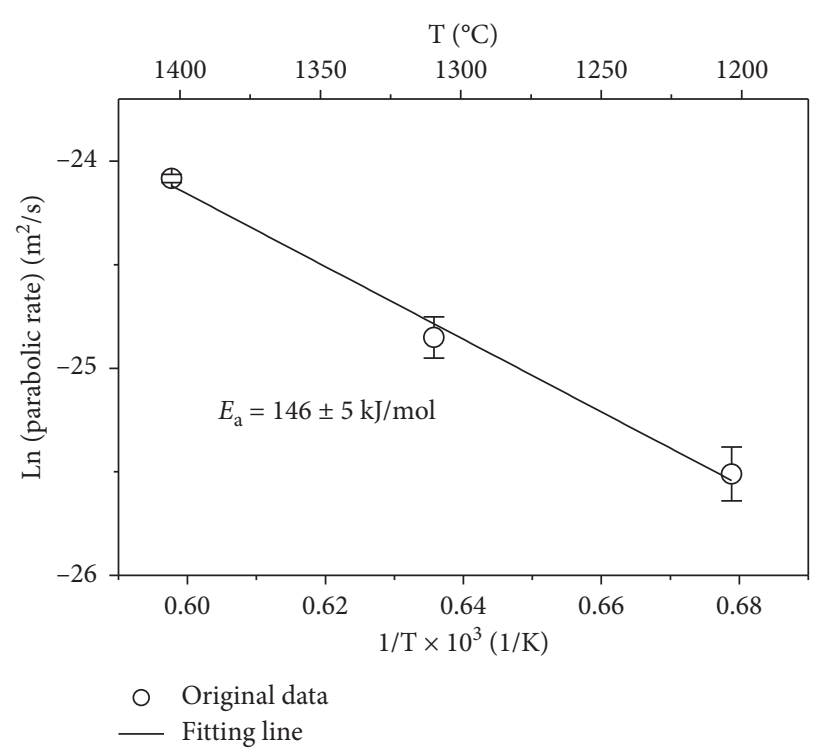

Figure 8: Arrhenius plots of parabolic oxidation rate as a function of temperature for the $\mathrm{SiC}$ layer oxidation in air atmosphere.

$1400^{\circ} \mathrm{C}$, devitrification of silica occurred, leading to the formation of $\alpha$-cristobalite. Originally, it was considered that oxygen permeability in amorphous silica is high; however, some studies suggest that it might be similar for $\alpha$-cristobalite. At higher temperatures, the viscous nature of silica may promote diffusion of oxygen. Some critical issues might arise, cristobalite undergoes a phase transformation associated with volume change during the cooling process that can lead to fracture and spallation. The formation of microcracks would provide the diffusion paths for oxygen and thus accelerated $\mathrm{SiC}$ oxidation significantly. Both the linear and parabolic oxidation rates of the $\mathrm{SiC}$ layers at $1400^{\circ} \mathrm{C}$ were almost triple those at $1300^{\circ} \mathrm{C}$.

\section{Conclusions}

The oxidation of TRISO particles with the outer layers of SiC in air environment was investigated at the temperature range of $900^{\circ} \mathrm{C}-1400^{\circ} \mathrm{C}$. The $\mathrm{SiC}$ layer had a good oxidation resistance at a temperature below $1100^{\circ} \mathrm{C}$. The silica formed was amorphous at $1200^{\circ} \mathrm{C}-1300^{\circ} \mathrm{C}$ and gradually crystallized at $1400^{\circ} \mathrm{C}$ with the major phase of $\alpha$-cristobalite. The presence of carbon was detected after oxidation above $1200^{\circ} \mathrm{C}$. Besides, the crystallization and phase transformation of silica resulted in the formation of cracks in the silica layer due to the volume change.
The thickness of the silica layer increased obviously with the increase of temperature. The oxidation kinetics of $\mathrm{SiC}$ followed the linear-parabolic law. Both the linear and parabolic oxidation rates were calculated according to the relationship between the thickness of the silica layer and the oxidation time. The calculated activation energy was $146 \pm 5 \mathrm{~kJ} / \mathrm{mol}$, suggesting that the rate-controlling step of the oxidation was the diffusion of the oxygen molecule in silica.

\section{Data Availability}

The data used to support the findings of this study are available from the corresponding author upon request.

\section{Conflicts of Interest}

The authors declare that they have no conflicts of interest.

\section{Acknowledgments}

The authors would like to acknowledge the funding from the projects supported by the Natural Science Foundation of Hunan Province (no. 2020JJ3487), The Research Foundation of Education Bureau of Hunan Province (no. 18C0450), The Opening Project of Cooperative Innovation Center for Nuclear Fuel Cycle Technology and Equipment (no. 2019KFY22), and College Students' Innovation and Entrepreneurship Training Program of Hunan Province (no. s201910555095).

\section{References}

[1] X. W. Zhou and C. H. Tang, "Current status and future development of coated fuel particles for high temperature gascooled reactors," Progress in Nuclear Energy, vol. 53, no. 2, pp. 182-188, 2011.

[2] P. A. Demkowicz, B. Liu, and J. D. Hunn, "Coated particle fuel: historical perspectives and current progress," Journal of Nuclear Materials, vol. 515, pp. 434-450, 2019.

[3] L. L. Snead, T. Nozawa, Y. Katoh, T.-S. Byun, S. Kondo, and D. A. Petti, "Handbook of $\mathrm{SiC}$ properties for fuel performance modeling," Journal of Nuclear Materials, vol. 371, no. 1-3, pp. 329-377, 2007.

[4] Z. Chen, X. Chen, Y. Zheng et al., "Air ingress analysis of chimney effect in the 200 MWe pebble-bed modular high temperature gas-cooled reactor," Annals of Nuclear Energy, vol. 106, pp. 143-153, 2017.

[5] C. I. Contescu, R. W. Mee, P. Wang, A. V. Romanova, and T. D. Burchell, "Oxidation of PCEA nuclear graphite by low water concentrations in helium," Journal of Nuclear Materials, vol. 453, no. 1-3, pp. 225-232, 2014.

[6] W. Xu, J. Sun, Y. Zheng, and L. Shi, "The influence of nuclear graphite oxidation on air ingress accident of HTR-PM," Annals of Nuclear Energy, vol. 110, pp. 1242-1248, 2017.

[7] J. J. Lee, T. K. Ghosh, and S. K. Loyalka, "Oxidation rate of graphitic matrix material in the kinetic regime for VHTR air ingress accident scenarios," Journal of Nuclear Materials, vol. 451, no. 1-3, pp. 48-54, 2014.

[8] W.-H. Huang, S.-C. Tsai, I.-C. Chiu, C.-H. Chen, and J.-J. Kai, "The oxidation effects of nuclear graphite during air-ingress 
accidents in HTGR," Nuclear Engineering and Design, vol. 271, pp. 270-274, 2014.

[9] L. Charpentier, M. Balat-Pichelin, and F. Audubert, "High temperature oxidation of $\mathrm{SiC}$ under helium with low-pressure oxygen-Part 1: sintered $\alpha$-SiC," Journal of the European Ceramic Society, vol. 30, no. 12, pp. 2653-2660, 2010.

[10] L. Charpentier, M. Balat-Pichelin, H. Glénat, E. Bêche, E. Laborde, and F. Audubert, "High temperature oxidation of $\mathrm{SiC}$ under helium with low-pressure oxygen. Part 2: CVD $\beta$-SiC," Journal of the European Ceramic Society, vol. 30, no. 12, pp. 2661-2670, 2010.

[11] K. Dawi, M. Balat-Pichelin, L. Charpentier, and F. Audubert, "High temperature oxidation of $\mathrm{SiC}$ under helium with lowpressure oxygen. Part 3: $\beta$-SiC-SiC/PyC/SiC," Journal of the European Ceramic Society, vol. 32, no. 2, pp. 485-494, 2012.

[12] S. Ueta, J. Sumita, T. Shibata et al., "R \& D plan for development of oxidation-resistant graphite and investigation of oxidation behavior of $\mathrm{SiC}$ coated fuel particle to enhance safety of HTGR," Nuclear Engineering and Design, vol. 271, pp. 309-313, 2014.

[13] C. Tang, B. Liu, Z. Li, Y. Quan, H. Zhao, and Y. Shao, "SiC performance of coated fuel particles under high-temperature atmosphere of air," Nuclear Engineering and Design, vol. 271, pp. 64-67, 2014.

[14] R. Liu, B. Liu, K. Zhang, M. Liu, Y. Shao, and C. Tang, "High temperature oxidation behavior of $\mathrm{SiC}$ coating in TRISO coated particles," Journal of Nuclear Materials, vol. 453, no. 1-3, pp. 107-114, 2014.

[15] K. A. Terrani and C. M. Silva, "High temperature steam oxidation of SiC coating layer of TRISO fuel particles," Journal of Nuclear Materials, vol. 460, pp. 160-165, 2015.

[16] D. Das, J. Farjas, and P. Roura, "Passive-oxidation kinetics of SiC microparticles," Journal of the American Ceramic Society, vol. 87, no. 7, pp. 1301-1305, 2004.

[17] M. A. Pimenta, G. Dresselhaus, M. S. Dresselhaus, L. G. Cançado, A. Jorio, and R. Saito, "Studying disorder in graphite-based systems by Raman spectroscopy," Physical Chemistry Chemical Physics, vol. 9, no. 11, pp. 1276-1290, 2007.

[18] H. Katsui, M. Oguma, T. Goto, and N. Jacobson, "Carbon interlayer between CVD $\mathrm{SiC}$ and $\mathrm{SiO}_{2}$ in high-temperature passive oxidation," Journal of the American Ceramic Society, vol. 97, no. 5, pp. 1633-1637, 2014.

[19] J. Eck, M. Balat-Pichelin, L. Charpentier, E. Bêche, and F. Audubert, "Behavior of $\mathrm{SiC}$ at high temperature under helium with low oxygen partial pressure," Journal of the European Ceramic Society, vol. 28, no. 15, pp. 2995-3004, 2008.

[20] B. E. Deal and A. S. Grove, "General relationship for the thermal oxidation of silicon," Journal of Applied Physics, vol. 36, no. 12, pp. 3770-3778, 1965.

[21] D. S. Fox, "Oxidation behavior of chemically-vapor-deposited silicon carbide and silicon nitride from $1200^{\circ} \mathrm{C}$ to $1600^{\circ} \mathrm{C}$," Journal of the American Ceramic Society, vol. 81, pp. 945-950, 1998.

[22] T. Goto and H. Homma, "High-temperature active/passive oxidation and bubble formation of CVD $\mathrm{SiC}$ in $\mathrm{O}_{2}$ and $\mathrm{CO}_{2}$ atmospheres," Journal of the European Ceramic Society, vol. 22, no. 14-15, pp. 2749-2756, 2002.

[23] J. Wang, L. Zhang, Q. Zeng, G. L. Vignoles, L. Cheng, and A. Guette, "The rate-limiting step in the thermal oxidation of silicon carbide," Scripta Materialia, vol. 62, no. 9, pp. 654-657, 2010. 